\title{
ПРОБЛЕМИ МІЖДИСЦИПЛІНАРНИХ ДОСЛІДЖЕНЬ У ЕПІДЕМІОЛОГІї АУТИЗМУ
}

\begin{abstract}
У статті здійснюється ретроспективний огляд «аутизму» як розладу. Розглядаються найбільш вагомі спроби щцодо систематизачї симптомокомплексу, епідеміологічних досліджень, дискусійність нижньої вікової межі діагностики. Аналізується ефективність напрямків психологічної складової у мультидисциплінарній комплексній допомозі, як от терапевтично-освітніх програм у поведінковому, сочіально-когнітивному та сенсорноінтегративному напрямках. Розробка та впровадження на загальнодержавному рівні ефективних та гуманних способів лікування та менеджменту розвитку для дітей з РСА є пріоритетом у розвитку його епідеміологї.
\end{abstract}

Ключові слова: аутизм, розлади спектру аутизму, розлади нейрологічного розвитку, дизонтогенез, епідеміологія.

The article is a retrospective review «autism» as a disorder. Considered the most significant attempts to systematize symptoms, epidemiological studies are considered debate about the lower age limit of diagnosis. Effectiveness analysis done trends psychological component in the multidisciplinary integrated care, like from therapeutic and educational programs in behavioral, social-cognitive and sensory-integrative directions. Development and implementation at the national level of effective and humane methods of treatment and development management for children with ASD is a priority in the development of its epidemiology.

Keywords: autism, autism spectrum disorders, disorders of development dizontogenesis, epidemiology.

Постановка наукової проблеми та її значення. Термін аутизм (autos - 3 гр. сам) ввів у психіатрію в 1911 році швейцарський психіатр Е. Блейлер для опису клінічної картини шизофренії, а саме - втечі хворого шизофренією у світ фантазій, щоб впоратися з нестерпними зовнішніми обставинами або травмуючим досвідом. Проте наукового обгрунтування симптоматики цього розладу у той час ще не відбулося.

Використання терміну «аутизм» в його нинішньому значенні почалось 30 років потому, коли австрійський лікар-педіатр Х. Аспергер використав термінологію Е. Блейлера про аутизм та опублікував свою другу кандидатську дисертацію в 1944 році (першу захистив у 1943 році), де він описав групу дітей та підлітків $з$ дефіцитами в комунікації та соціальних навичках, а також з обмеженими інтересами та повторюваною моделлю поведінки. У той же час, в 1943 році, Л. Каннер та Дж. Хопкінс в Університетській клініці в США у своїх працях у 1943 р. описують 11 дітей з яскравими поведінковими особливостями, аналогічними до зображених Х. Аспергером. Більшість ключових характеристик, описаних Л. Каннером, такі як «аутистичне відчуження» і «наполягання на однотипності» стають критеріями для діагностики раннього дитячого аутизму (РДА) в подальших класифікаціях. Власне Л. Каннер ввів термін «ранній 
дитячий аутизм» (РДА), оскільки на той час ще не було жодних відомостей, що ж трапиться із розвитком таких дітей у дорослому віці. На сьогоднішній день термін РДА менш вживаний та необгрунтований. Симптоми описуються X. Acпергером дещо відмінно від Л. Каннера, вказуючи, що у ранньому віці у таких дітей немає когнітивних дефіцитів.

Праця X. Аспергера, яка була опублікована німецькою мовою, залишалася невідомою до того часу, допоки Ута Фріт не переклала іiі на англійську, зробивши іiі широко доступною. Л. Вінг поширив ці ідеї у Великобританії [1]. Трохи згодом, Л. Каннер і його послідовник Л. Ейзенберг класифікують аутизм, грунтуючись на основі спостереження і опису п'яти діагностичних критеріїв: відсутність емоційного контакту з іншими людьми; сильна потреба в незмінності навколишнього середовища, захоплення об'єктами і стереотипність поведінки; відсутність мовлення або не використання мови для спілкування; високий потенціал когнітивних і спеціальних здібностей. Л. Каннер виділяє і додаткові клінічні ознаки, не включені в основні діагностичні критерії. До них відносяться: недоліки в невербальній комунікації, соціальній взаємодії; проблеми координації рухів; стереотипні рухи тіла і кінцівок; специфічні відповіді на сенсорні стимули; ехолалія; труднощі з харчуванням; агресія, автоагресія, деструктивна поведінка [8].

Аналіз та порівняння останніх досліджень проблеми. Після відкриття аутизму ще протягом багатьох років він розглядався як синдром. Але поступово науковці дійшли думки, що визнання аутизму як синдрому звужує природу цього розладу. Вперше запропонували більш ширший розгляд аутизму Л. Вінг та Дж. Гоулд [11]. Вони визначили аутизм як спектр, що охоплює осіб, у яких з'являються навіть найменші прояви тріади дефіциту: 1) ускладненої соціальної взаємодії, 2) вербального і невербального спілкування, 3) збідненої уяви. Таким чином, класифікація спектру аутизму почала включати і класичний аутизм, $\mathrm{i}$ аутичні риси, а також схожі розлади.

Дещо іншого погляду на аутизм дотримується Кр. Гілберг, який ставився до аутизму як до порушення емпатії. Він стверджував, що діти, які страждають аутизмом, не можуть співпереживати досвіду інших людей, не здатні розпізнавати емоції, а тому не здатні до емпатії. У класифікації, запропонованій Кр. Гілберг аутизм входить в групу інших розладів, які характеризуються відхиленнями у розвитку емпатії. Окрім аутизму, в цю групу розладів він включав також дезінтегративні розлади, розлад Аспергера, селективний мутизм та анорексію [6]. Дослідження нейропсихологів справді підтверджують деякі спільні властивості мозкових дисфункцій цих розладів. Проте їх причини не мають на сьогодні єдиного прийнятного обгрунтування.

Серед досліджень, присвячених епідеміології аутизму ще одним важливим і досі повною мірою не з'ясованим питанням $є$ статева схильність до появи розладу. Дослідження дають нам різні дані: співвідношення хлопчиків і дівчат в розмірі 3 до 1; 4 до 1, або і 5,7 до 1 [5]. Незважаючи на розбіжності в результатах, отриманих дослідниками, можемо однозначно стверджувати про більш високий рівень аутизму у хлопчиків. Така особливість $є$ важливою підставою формулювання біологічних та нейрологічних концепцій аутизму. 
Наявність соціальної детермінації також ставала предметом наукового дослідження. До уваги також брався такий фактор, як зростання свідомості населення щодо проблеми аутизму. Так, Б. Рімланд у Інституті досліджень аутизму в Сан-Дієго (1995р.), вказує на такі причини зростання кількості випадків аутизму: забруднення середовища пластиком, часте застосування антибіотиків, деякі вакцинації, приймання матір'ю протисудомних препаратів, вірусні інфекції. Ряд екологічних факторів також перевірялись щодо їх ролі в етіології РСА, такі як ртуть, кадмій, нікель, трихлоретилен і хлористий вініл [7]. Інші дослідження не виключають впливу сьогочасних умов життя, особливостей демографічної ситуації (як от, народження дітей у батьків більш старшого віку, сприяння виживанню недоношених немовлят, рання діагностика розладів у дітей) - все це умови кількісних зростань статистики РСА.

Пояснення аутизму в порівнянні з іншими розладами, зазнали особливо істотних змін протягом останніх 20 років. Ці зміни чітко помітні в динаміці двох основних систем класифікації: Міжнародній класифікації хвороб (МКХ) Всесвітньої організації охорони здоров’я (ВОO3), а також статистичному керівництві по психічних розладах (DSM) Американської психіатричної асоціації (APA). У МКХ-8 від ВОО3 у 1967 році, аутизм був класифікований як атипова форма шизофренії. У цій класифікації було взято до уваги лише дитячий аутизм. I тільки після публікації DSM-III у 1980 році, аутизм більше не класифікується як психоз. У DSM-III термін аутизм характеризується як глибокі порушення розвитку. Інші системи класифікації, які виникли після DSM-III вже забезпечують аналогічну класифікацію аутизму. У DSM-IV, термін «глибокі розлади розвитку» охоплюють групу значущих і поширених розладів, які починають з'являтися ще від початку життя дитини і характеризується порушеннями в трьох сферах: соціалізації, комунікації та стереотипній і персевераційній поведінці.

У DSM-V (2013 р.) були усунені відмінності між аутизмом, синдромом Ретта, синдромом Аспергера, пояснюючи, що розлади дитинства є надзвичайно руйнівні і поширені, а тому мають глибокий вплив на весь розвиток дитини. Тут також визначені унікальні характеристики РСА: постійні дефіцити в соціальній комунікації та соціальної взаємодії через нездатність схоплювати мультиконтекстність ситуацій; обмежені, повторювані моделі поведінки, інтереси у діяльності; клінічно виразне знецінення соціальної, професійної або інших важливих сфер функціонування; не пояснюється інтелектуальною інвалідністю або глобальною затримкою розвитку.

Аналіз епідеміологічних джерел засвідчує, що кількість людей, які страждають на аутизм $з$ кожним роком зростає. Перші епідеміологічні дослідження були проведені ще в 1966 році Б. Лоттер в Великобританії [9]. Б. Лоттер вивчав дітей у віці від восьми до десяти років. Дослідження починались із заповнення анкети вчителями в школах, а далі відбувалось індивідуальне обстеження дітей, зарахованих до групи ризику. Було встановлено, що захворюваність на аутизм становила від 0,7 до 2,0 на 10000 дитячої популяції. Інші спроби епідеміологічних досліджень дають дуже різні результати. Дослідження, проведені у 80-ті ро- 
ки показали частоту захворювання на аутизм в межах 4 осіб на 10 000, в той час як дані з 90-х років показали 10-20 осіб на 10000 [9].

Нещодавно у США Центри з контролю і профілактики захворювань (Centers for Disease Control and Prevention) оприлюднили дані досліджень (2014 р.), згідно з якими у 1 з 67 дітей спостерігаються РСА (у 1 з 42 хлопців та у 1 з 189 дівчат), в той час як у 2010 році ці показники фіксувалися на рівні 1 дитиниаутиста з 88 типових дітей, а у 2008 році 1 зі 110. [4]. Порівнюючи епідеміологічні дані, виникає цілком логічне запитання, чому ж так прогресує кількість осіб з аутизмом? Як відзначають дослідники, зокрема Е. Пісула, основною причиною збільшення числа осіб, що страждають на аутизм, є зміна в способі діагностики розладу. Достовірність результатів обумовлена мірою стандартизації діагностичних критеріїв і визначенням гранично низького віку, у який рекомендовано ставити діагноз.

В Україні ситуація є типовою для пострадянського простору. До 1980-х років у нашій державі розлади спектру аутизму не діагностувалися. Поширеність розладів 32008 р. по 2013 р. зросла в 3,5 рази: з 13,8 до 48,2 на 100000 дитячого населення. Показник стабільно зростав упродовж останніх семи років: у 2007 р. на 28,2\%; у 2008 р. на 32\%; у 2009 р. на 27,2\%; у 2010 р. на 35,7\%; у 2011 р. на 21,2\%; у 2012 р. на 25,3\%; у 2013 р. на 38\%. [2, с. 122]. Зважаючи на порівняльний аналіз таких епідеміологічних показників, очевидно давно назріли зміни у сфері охорони психічного здоров'я дітей та підлітків.

Сьогодні аутизм визнається нейророзвитковим розладом, тому його особливості змінюються залежно від віку дитини та їі навичок. Для того, щоб правильно поставити діагноз аутизм, необхідно виключити інші розлади зі спектру порушень розвитку. Зокрема, диференційна діагностика аутизму та розумової відсталості $є$ одним $з$ ключових завдань, зважаючи на високу ймовірність коморбідності та схожість у окремих показниках когнітивного розвитку [3]. Проте, трирічний вік як нижня межа встановлення діагнозу теж на сьогодні визнається проблемою, оскільки унеможливлює надання ранньої спеціалізованої допомоги. Виникає запитання: чи можна виявити аутизм у дітей більш раннього віку?

Даний тип дизонтогенезу призводить до важких розладів організації взаємин дитини зі світом, що закономірно виводить на перший план дослідження, що орієнтовані на ранній дитячий вік. Згідно останніх наукових досягнень, перший рік життя дитини з аутизмом досі дає нам тільки поодинокі підказки у виокремленні ранньої симптоматики. Це не означає, що батьки не помічають особливостей або регресу розвитку дитини на цій ранній стадії розвитку. Найбільш очевидними є труднощі з мовленням дитини, які, як правило, стають добре помітні у віці від 15 до 36-місячного віку. Регрес у спілкуванні зазвичай супроводжується ускладненням соціальних контактів, ізоляцією, стреотипізацією поведінки [10, с. 30]. Існує гіпотеза про те, що втрата ранніх комунікативних навичок може викликатися переживанням травми, наприклад, госпіталізацією, хворобливими процедурами, відокремленням від матері. Але досі надійних підстав для підтвердження таких гіпотез є недостатньо. 
Намагаючись визначити ранні ознаки, які передують діагнозу РСА у братів і сестер за допомогою ретроспективного аналізу аномального розвитку, вчені виокремили проспективні особливості дітей, що потрапляють у зону ризику. Було з'ясовано, що серед немовлят, що мають високий ризик РСА, відсутніми є будь які істотні відмінності протягом перших шести місяців життя. Тим не менш, в наступних шести місяцях, проблеми соціальної взаємодії стають очевидними. У подальших лонгітюдних дослідженнях сиблінгів дітей 3 аутизмом (найвищий рівень ризику мати РСА) були виокремлені поведінкові та нейроанатомічні маніфестації аутизму. Вже дворічні малюки 3 РСА мають очевидні проблеми соціальної комунікації, гри, мови та пізнання, а також інші сенсорні й моторні ознаки. Ці результати досліджень підтверджують думку, що РСА можуть бути діагностовані раніше, ніж їх зазвичай ідентифікують. Існує гіпотеза, що саме у віці 24 місяців з'являються нові симптоми, які й полегшують виявлення [12].

РСА є пожиттєвим розладом. На підтвердження цього, дослідники встановили, що 78\% осіб у Німеччині, яким у дитинстві був встановлений діагноз РCA і надалі проявляли девіантну поведінку і труднощі в соціальних взаємодіях протягом усього їх життя. Вони потребували підтримки і допомоги в багатьох сферах. Тим не менш, якість їхнього життя може бути істотно покращена, коли надається доступ до адекватних програм оптимізації розвитку [11]. Такі програми повинні брати до уваги труднощі та сильні сторони, а також ресурси, що забезпечує спільнота. Таким чином, поведінка й адаптивні навички, як правило, піддаються вдосконаленню з віком.

3 метою нормалізації функціонування дитини з аутизмом у суспільстві було розроблено вже чимало терапевтично-освітніх програм у поведінковому, соціально-когнітивному та сенсорно-інтегративному напрямках. Ключовою прогресивною ознакою при аутизмі визначено інтерес дитини до навколишнього світу. Такий інтерес спонукає появу мовлення та зниження кількості стереотипій дитини.

Для подальшої успішної терапевтично-освітньої роботи необхідним $є$ створення комплексного плану навчання і терапії дитини у тісній співпраці між мультидисциплінарною командою та батьками дитини. Роль батьків тут максимально відповідальна. Саме у 60-х роках минулого століття поведінкові терапевти вперше почали залучати батьків до програми реалізації. Найбільшою перевагою такої терапії є природні умови середовища. Клінічний досвід показує, що тільки ті діти, з якими працювали батьки зберегли свої навички і часто досягали подальшого прогресу. Тому навчання і підтримка батьків у таких програмах є ключовим елементом успіху. Окрім залучення у терапевтично-освітні програми батьків, важливим залишається впровадження індивудуалізованого, чітко структурованого і передбаченого, інтенсивного та пролонгованого у часі навчання. На сьогоднішній день вчені і досі шукають ефективні та гуманні способи лікування та менеджменту розвитку для дітей з РСА. Проте, кращим засобом і далі визнається рання точна діагностика та подальша комплексна ерготерапія. 
Висновки і перспективи подальших досліджень. Оскільки діагностичні помилки щодо виявлення аутизму не є рідкістю і сьогодні, багато дослідників підкреслюють важливість стандартизації методів діагностики і використання чітких діагностичних критеріїв. Незважаючи на безперервні дослідження i вдосконалення діагностичного процесу, проблема диференціації аутизму та інших розладів як і раніше присутня. І досі часто трапляються помилки у розмежуванні аутизму та розумової відсталості, мовленнєвих розладів. Проблема диференційованості часто супроводжує розлади аутизму і шизофренії чи інших комплексних порушень розвитку (синдром Ретта, синдром Аспергера, дитячі дезінтеграційні розлади). Аутизм протягом більше 70 років викликає зростаючий інтерес у дослідників різних галузей, i, очевидно, буде інтригувати ще багато років, оскільки залишається одним 3 найбільш руйнівних розладів 3 точки зору поширеності захворювання, впливу на сім'ю та дороговартісності для адаптації в суспільстві.

1. Богдашина О. Аутизм. Определение и диагностика. Донецк : Лебедь, 1999. 112 с.

2. Когутяк Н. М. Методологічні пошуки у діагностичних дослідженнях типових когнітивних дефіцитів при розладах спектру аутизму. Науковий теоретико-методологічний $i$ прикладний психологічний журнал «Психологія особистості». Івано-Франківськ : Вид-во Прикарпатського національного університету імені Василя Стефаника, 2014. Вип. 1 (5). C. $120-132$.

3. Островська К. О. Диференційна діагностика дітей з аутизмом: психологічний аспект. Вісник Львівського університету. Серія : Філософські науки. 2013. Вип. 16. С. 221-231. URL: http://nbuv.gov.ua/UJRN/Vlnu_philos_2013_16_27.

4. Очерки детской психиатрии. Аутизм: учебное пособие для спещиалистов в области охраны психического здоровья детей / под ред. главного внештатного специалиста МЗ Украины по специальности «детская психиатрия» И. А. Марценковского. НейроNEWS. 2014. $280 \mathrm{c}$.

5. Bobkowicz-Lewartowska L. Autyzm dziecięcy. Zagadnienia diagnozy i terapii. Kraków : Impuls, 2014. $156 \mathrm{~s}$.

6. Gillberg C. Harrington R., Steinhausen H-Ch. Autism Spectrum Disorders. A Clinician's Handbook of Child and Adolescent. Eds. Cambridge University Press, 2006. P. 447. ISBN 0521-81936-9.

7. Evans B. How autism became autism. The radical transformation of a central concept of child development in Britain. Hist Human Sci. 2013. Jul. № 26 (3). P. 3-31. Review. PMID: 24014081.

8. Kanner L., Eisenberg L. Early Infantile Autism 1943-1955. American Journal of Orthopsychiatry. 1956. № 26. P. 55-65. Reprinted in : Alexander et al., eds. Op. cit. Reprinted in Psychiat. Res. Repts. 1957 (April), American Psychiatric Assn., P. 55-65.

9. Pisula E. Autyzm u dzieci: diagnoza, klasyfikacja, etiologia. Warszawa : Wydawnictwo Naukowe PWN. 2000. $234 \mathrm{~s}$.

10. Pisula E. Małe dziecko z autyzmem. Diagnoza i terapia. Gdańsk : Gdańskie Wydawnictwo Psychologiczne. 2005. $126 \mathrm{~s}$.

11. Wing L. Gould J. Severe impairments of social interaction and associated abnormalities in children: epidemiology and classification. Autism Dev Disord. 1979. Mar. № 9 (1). P. 11-12. PubMed PMID: 155684.

12. Zwaigenbaum L., Bryson S., Roberts W., Brian J., Szatmari P. Behavioral markers of autism in the first year of life. Int J Dev Neurosci. 2005. № 23. P. 143-152. 